\title{
Manajemen Keluarga dan Masyarakat
}

\author{
Noor Hafidhoh, Anik Indramawan \\ Institut Agama Islam Pangeran Diponegoro Nganjuk
}

Email: noorhafidhoh@gmail.com

\begin{abstract}
Abstrak: Tanggung jawab dalam pendidikan tidak saja tertumpu pada pihak sekolah sebagai penyelenggara pendidikan formal, akan tetapi menjadi tanggungjawab terutama bagi orang tua, dalam hal ini keluarga dan juga masyarakat. Peran keluarga dan masyarakat dalam pendidikan sangatlah besar. Berhasil tidaknya sebuah proses pendidikan tidak semata-mata tergantung pada pihak sekolah akan tetapi justru pada keluarga dan masyarakat. Untuk itu membangun hubungan yang baik dan harmonis antara keluarga dan sekolah, antara masyarakat dan sekolah sangat perlu, penting dan urgent. Dan bagi seorang pendidik sebagai salah satu pioneer pendidikan, sangatlah perlu untuk memahami betapa penting peran keluarga dan masyarakat dalam pendidikan sebagai salah satu visi dalam menjalankan proses pendidikan.
\end{abstract}

Kata kunci : Peran Keluarga, Peran Masyarakat, Hubungan Keluarga dan masyarakat

\section{A. Pendahuluan}

Dilihat dari segi pendidikan, keluarga merupakan satu kesatuan hidup (sistem nasional), dan keluarga menyediakan situasi belajar. Sebagai satu kesatuan hidup bersama (sistem sosial), keluarga terdiri dari ayah, ibu, dan anak. Ikatan kekeluargaan membantu anak mengembangkan sifat persahabatan, cinta kasih, hubungan antarpribadi, kerja sama, disiplin, tingkah laku yang baik, serta pengakuan akan kewibawaan.

Namun disayangkan kurangnya komunikasi terhadap orang tua siswa dengan guru yang mengajar dan sekolah dimana tempat anaknya dititipkan untuk menuntut ilmu pendidikan. Dengan kurangnya komunikasi pada ke tiga elemen ini membuat ketidak seimbangan informasi terhadap anak didiknya baik pada saat berada di sekolah maupun dirumah.

Agar bisa memajukan pendidikan perlu adanya komunikasi antara sekolah dan orang tua murid agar bisa menyesuaikan cara belajar yang baik untuk meningkatkan motivasi anak untuk belajar lebih rajin. Jika komunikasi 
ini berjalan dengan baik tentu bisa meningkatkan kecerdasan anak yang diinginkan baik dari orang tua dan sekolah.

Hal yang menjadi permasalahan dalam jurnal ini adalah:

1. Bagaimana Peranan Keluarga dan dalam Pendidikan ?

2. Bagaimana kerjasama antara pihak sekolah dan keluarga?

3. Bagaimana peran masyarakat dalam pendidikan?

4. Bagaimana hubungan masyarakat dan sekolah?

Berdasar dari rumusan masalah tersebut maka tujuan penulisan jurnal ini adalah:

1. Mengetahui peran keluarga dalam pendidikan

2. Mengetahui seberapa jauh kerjasama antara keluarga dan sekolah dalam pendidikan

3. Mengetahui peran masyarakat dalam pendidikan

4. Mengetahui hubungan masyarakat dan sekolah dalam pendidikan

\section{B. PEMBAHASAN}

\section{Peran Keluarga dalam Pendidikan}

Dilihat dari segi pendidikan, keluarga merupakan satu kesatuan hidup (sistem nasional), dan keluarga menyediakan situasi belajar. Sebagai satu kesatuan hidup bersama (sistem sosial), keluarga terdiri dari ayah, ibu, dan anak. Ikatan kekeluargaan membantu anak mengembangkan sifat persahabatan, cinta kasih, hubungan antarpribadi, kerja sama, disiplin, tingkah laku yang baik, serta pengakuan akan kewibawaan.

Sementara itu, yang berkenaan dengan keluarga menyediakan situasi belajar, dapat dilihat bahwa bayi dan anak sangat bergantung kepada orang tua, baik karena keadaan jasmaniahnya maupun kemampuan intelektual, sosisal, dan moral. Bayi dan anak belajar menerima dan meniru apa yang diajarkan oleh orang tua.

Sumbangan keluarga bagi pendidikan anak-anak adalah sebagai berikut:(Hasbullah, 88 : 2009) 
1. Cara orang tua melatih anak untuk menguasai cara-cara mengurus diri, seperti cara makan, buang air, berbicara, berjalan, berdoa, sungguh-sungguh membekas dalam diri anak karena berkaitan erat dengan perkembangan dirinya sebagai peribadi.

2. Sikap orang tua sangat mempengaruhi perkembangan anak. Sikap menerima atau menolak, sikap kasih saying atau acuh tak acuh, sikap sabar atau tergesa-gesa, sikap melindungi atau membiarkan secara langsung mempengaruhi reaksi emosional anak.

Sangat wajar dan logis jika tanggung jawab pendidikan terletak di tangan kedua orang tua dan tidak bisa dipikulkan kepada orang lain karena ia adalah darah dagingnya, kecuali berbagai keterbatasan orang tua ini. Maka sebagian tanggung jawab pendidikan dapat dilimpahkan kepada orang lain yaitu sekolah.

Tanggung jawab pendidikan yang perlu disandarkan dan dibina oleh kedua orang tua terhadap anak antara lain: (M. Arifin, 257-258 : 1991)

1. Memelihara dan membesarkannya, tanggung jawab ini merupakan dorongan alami untuk dilaksanakan karena si anak memerlukan makan, minum, dan perawatan agar ia dapat hidup secara berkelanjutan.

2. Melindungi dan menjamin kesehatannya, baik secara jasmaniah maupun rohaniah dari berbagai gangguan penyakit atau bahaya lingkungan yang dapat membahayakan dirinya.

3. Mendidiknya dengan berbagai ilmu pengetahuan dan keterampilan yang berguna bagi kehidupannya kelak sehingga bila ia telah dewasa mampu berdiri sendiri dan membantu orang lain.

4. Membahagiakan anak untuk dunia dan akhirat dengan memberinya pendidikan agama sesuai dengan ketentuan Allah Swt, sebagai tujuan akhir hidup muslim.

Adanya kesadaran akan tanggung jawab mendidik dan membina anak secara kontinu perlu dikembangkan kepada setiap orang tua sehingga pendidikan yang dilakukan tidak berdasarkan kebiasaan yang dilihat dari orang 
tua, tetapi telah didasari oleh teori-teori pendidikan modern, sesuai dengan perkembangan zaman yang cenderung selalu berubah.

Tugas utama keluarga bagi pendidikan anak ialah sebagai peletak dasar bagi pendidikan akhlak dan pandangan hidup keagamaan. Sifat dan tabiat anak sebagian besar diambil dari kedua orang tuanya dan dari anggota keluarga yang lain.

\section{Kerja Sama antara Keluarga dengan Sekolah}

Di dalam UU Nomor 2 tahun 1989 tentang Sistem Pendidikan Nasional Pasal 10 ayat (4) dinyatakan bahwa: pendidikan keluarga merupakan bagian dari jalur pendidikan luar sekolah yang diselenggarakan dalam keluarga dan yang memberikan keyakinan agama, nilai budaya, nilai moral, dan keterampilan. Sementara itu, dalam GBHN 1993 dinyatakan:

"Pendidikan nasional dikembangkan secara terpadu dan serasi baik antarberbagai jalur, jenis, dan jenjang pendidikan, maupun antara sektor pembangunan lainnya serta antardaerah. Masyarakat sebagai mitra pemerintah berkesempatan seluas-luasnya untuk berperan serta dalam penyelenggaraan pendidikan nasional". (Tap MPR, 90: 1993)

Pendidikan adalah tanggung jawab bersama antara keluarga, masyarakat, dan pemerintah. Sekolah hanyalah pembantu kelanjutan pendidikan dalam keluarga sebab pendidikan yang pertama dan utama diperoleh anak adalah dalam keluarga. Peralihan bentuk pendidikan jalur luar sekolah ke jalur pendidikan sekolah (formal) memerlukan "kerja sama" anatara orang tua dan sekolah (pendidik).

Sikap anak terhadap sekolah terutama akan dipengaruhi oleh sikap orang tuanya. Begitu juga sangat diperlukan kepercayaan orang tua terhadap sekolah (pendidik) yang menggantikan tugasnya selama di ruangan sekolah. Hal ini sangat penting untuk diperhatikan, mengingat akhir-akhir ini sering terjadi tindakan-tindakan kurang terpuji dilakukan anak didik, sementara orang tua seolah tidak mau tahu, bahkan cenderung menimpakan kesalahan kepada sekolah. 
Orang tua harus memperhatikan sekolah anaknya, yaitu dengan memperhatikan pengalaman-pengalamannya dan menghargai segala usahanya. Begitu juga orang tua harus menunjukkan kerjasamanya dalam mengarahkan cara anak belajar di rumah, membuat pekerjaan rumahnya, tidak disita waktu anak dengan mengerjakan pekerjaan rumah tangga, orang tua harus berusaha memotivasi dan membimbing anak dalam belajar.

Berdasarkan hasil riset bahwa pekerjaan guru (pendidik) di sekolah akan lebih efektif apabila dia mengetahui latar belakang dan pengalaman anak didik di rumah tangganya. Anak didik yang kurang maju dalam pelajaran berkat kerja sama orang tua anak didik dengan pendidik, banyak kekurangan anak didik yang dapat diatasi. Lambat laun juga orang tua menyadari bahwa pendidikan atau keadaan lingkungan rumah tangga dapat membantu atau menghalangi kesukaran anak di sekolah.

Apa-apa yang dibawa anak didik dari keluarganya, tidak mudah mengubahnya. Kenyataan ini harus benar-benar disadari dan diketahui oleh pendidik.

Pada dasarnya cukup banyak cara yang dapat ditempuh untuk menjalin kerja sama antara keluarga dengan sekolah. Berikut ini beberapa contohnya.

1. Adanya Kunjungan ke Rumah Anak Didik

Pelaksanaan kunjungan ke rumah anak didik ini berdampak sangat positif, di antaranya: (Hasbullah, 92)

a. Kunjungan melahirkan perasaan pada anak didik bahwa sekolahnya selalu memerhatikan dan mengawasinya.

b. Kunjungan tersebut member kesempatan kepada si pendidik melihat sendiri dan mengobservasi langsung cara anak didik belajar, latar belakang hidupnya, dan tentang masalh-masalah yang dihadapinya dalam keluarga.

c. Pendidik berkesempatan untuk memberikan penerangan kepada orang tua anak didik tentang pendidikan yang baik, cara-cara menghadapi maslah-masalh yang sedang dialami anaknya (kalau anaknya bermasalah), dan sebagainya. 
d. Hubungan antara orang tua dengan sekolah akan bertambah erat.

e. Kunjungan dapat memberikan motivasi kepada orang tua anak didik untuk lebih terbuka dan dapat bekerja sama dalam upaya memajukan pendidikan anaknya.

f. Pendidik mempunyai kesempatan untuk mengadakan interview mengenai berbagai macam keadaan atau kejadian tentang sesuatu yang ingin ia ketahui.

g. Terjadinya komunikasi dan saling memberikan informasi tentang keadaan anak serta saling member petunjuk anatara guru dengan orang tua.

2. Diundangnya Orang Tua ke Sekolah

Kalau ada berbagai kegiatan yang diselenggarakan oleh sekolah yang memungkinkan untuk dihadiri oelh orang tua, maka akan positif sekali artinya bila orang tua diundang untuk datang ke sekolah. Kegiatan-kegiatan dimaksud umpamanya class meeting yang berisi perlombaan-perlombaan yang mendemonstrasikan kebolehan anak dalam berbagai bidang, pameran hasil kerajinan tangan anak, pemutaran film pendidikan, dan sebagainya.

\section{Case Conference}

Case Conference merupakan rapat atau konferensi tentang kasus. Biasanya digunakan dalam bimbingan konseling. Peserta konferensi ialah orang yang betul-betul mau ikut membicarakan masalah anak didik secaraa terbuka dan sukarela, seperti orang tua anak didik, guru-guru, petugas bimbingan yang lain, dan para ahli yang ada sangkut pautnya dengan bimbingan seperti social worker dan sebagainya. Konferensi biasanya dipimpin oleh orang yang paling mengetahui persoalan bimbingan konseling, khususnya tentang kasus dimaksud.

Semua data dari "commulative record" anak didik dipergunakan, kalau memungkinkan didemonstrasikan. Materi dari pembicaraan di dalam konferensi bersifat confidential (di jaga 
kerahasiannya), sesuai dengan sifat kerahasiaan peruses bimbingan konseling.

Konferensi tersebut bertujuan mencari jalan yang paling tepat agar masalah anak didik dapat diatasi dengan baik. Biasanya hasil konferensi akan lebih baik karena data dikumpulkan oleh beberapa orang, serta interpretasi, analisis dan penentuan diagnosis suatu masalah dilakukan dengan sistem musyawarah mufakat.

4. Badan Pembantu Sekolah

Badan pembantu sekolah ialah organisasi orang tua murid atau wali murid dan guru. Organisasi dimaksud merupakan kerja sama yang paling terorganisasi anatara sekolah atau guru dengan orang tua murid.

Sampai sekarang, organisasi ini telah beberapa kali mengalami perubahan nama karena disesuaikan dengan perkembangan situasi pendidikan dan masyarakat pada mulanya organisasi ini bernama Perkembangan Orang Tua Murid dan Guru (POMG), kemudian berusaha menjadi Persatuan Orang Tua Murid (POM), Badan Pembantu Penyelenggara Pendidikan (BP3), dan sekarang dikenal dengan istilah Komite Sekolah.

5. Mengadakan Surat Menyurat anatara Sekolah dan Keluarga

Surat-menyurat ini diperlukan terutama pada waktu-waktu yang sangat diperlukan bagi perbaikan pendidikan anak didik, seperti surat peringatan dari guru kepada orang tua jika anaknya perlu lebih giat, sering membolos, sering berbuat keributan, dan sebagainya.

Surat-menyurat ini juga sebenarnya sangat baik bila dilakukan oleh orang tua kepada guru atau langsung kepala sekolah / madrasah untuk memantau keadaan anak didiknya di sekolah.

6. Adanya Daftar Nilai atau Raport

Raport biasanya diberikan setiap catur wulan kepada murid ini dapat dipakai sebagai penghubung antara sekolah dengan orang tua. Sekolah dapat member surat peringatan atau meminta bantuan orang 
tua bila hasil raport anaknya kurang baik, atau sebaliknya jika anaknya mempunyai keistimewaan dalam suatu mata pelajaran, agar dapat lebih giat mengembangkan bakatnya atau minimal mampu mempertahankan apa yang sudah dapat diraihnya.

\section{Peran Masyarakat dalam Pendidikan}

Sebagaimana yang dikemukakan terdahulu, bahwa masyarakat merupakan lembaga ketiga sebagai lembaga pendidikan, dalam konteks penyelenggaraan pendidikan itu sendiri besar sekali perannya. Bagaimanapun kemajuan dan keberadaan suatu lembaga pendidikan sangat ditentukan oleh peran serta masyarakat yang ada. Tanpa dukungan dan partisipasi masyarakat, jangan diharapkan pendidikan dapat berkembang dan tumbuh sebagaimana yang diharapkan.

Oleh karena itu, sebagai salah satu lingkungan terjadinya kegiatan pendidikan, masyarakat mempunyai pengaruh sangat besar terhadap berlangsungnya segala aktivitas yang menyangkut masalah pendidikan. Apalagi bila dilihat dari materi yang digarap, jelas kegiatan pendidikan baik yang termasuk jalur pendidikan sekolah maupun yang jalur pendidikan luar sekolah, berisikan generasi muda yang akan meneruskan kehidupan masyarakat itu sendiri. Untuk itu bahan apa yang akan diberikan kepada anak didik sebagai generasi tadi harus disesuaikan dengan keadaan dan tuntunan masyarakat di mana kegiatan pendidikan berlangsung.

Berikut ini adalah beberapa peran dari masyarakat terhadap pendidikan (sekolah).(Abdul Manan, 173: 2004)

1. Masyarakat berperan serta dalam mendirikan dan membiayai sekolah.

2. Masyarakat berperan dalam mengawasi pendidikan agar sekolah tetap membantu dan mendukung cita-cita dan kebutuhan masyarakat.

3. Masyarakatlah yang ikut menyediakan tempat pendidikan seperti gedunggedung museum, perpustakaan, panggung-panggung kesenian, kebun binatang, dan sebagainya. 
4. Masyarakat yang menyediakan berbagai sumber untuk sekolah. Mereka dapat diundang ke sekolah untuk memberikan keterangan-keterangan mengenai suatu masalah yang sedang dipelajari anak didik. Orang-orang yang mempunyai keahlian khusus banyak sekali terdapat di masyarakat, seperti petani, peternak, saudagar, polisi, dokter, dan sebagainya.

5. Masyrakatlah sebagai sumber pelajaran atau laboratorium tempat belajar.

Dengan demikian, jelas sekali bahwa peran masyarakat sangatlah besar terhadap pendidikan sekolah. Untuk itu, sekolah perlu memanfaatkannya sebaikbaiknya, paling tidak bahwa pendidikan harus dapat mempergunakan sumbersumber pengetahuan yang ada di masyarakat dengan alasan sebagai berikut:(Abdul Manan, 175)

1. Dengan melihat apa yang terjadi di masyarakat, anak didik akan mendapatkan pengalaman langsung (first hand experience) sehingga mereka dapat memiliki pengalaman yang konkret dan mudah diingat.

2. Pendidikan membina anak-anak yang bersal dari masyarakat, dan akan kembali ke masyarakat.

3. Di masyarakat banyak sumber pengetahuan yang memungkinkan guru sendiri dalam mengetahuinya.

4. Kenyataan menunjukkan bahwa masyarakat membutuhkan orang-orang yang terdidik dan anak didik pun membutuhkan masyarakat.

\section{Hubungan Masyarakat dengan Sekolah}

Masyarakat yang disamakan dengan istilah community atau society, diartikan sebagai: "A community is a group or a collection of groups that in habits a locality". (Ogburn \& Nimkolf, 291: 1964). Menurut pengertian ini masyarakat adalah satu kelompok atau sekumpulan yang mendiami suatu daerah.

Sementra itu, Prof. Robert W. Richey memberikan batasan tentang masyarakat sebagai berikut: "The tern community refers to a group of people living together in a region where common ways of thinking and acting make the in habitans somewhat aware of them selves as a group" (Robert, 489: 1968) 
Istilah masyarakat dapat diartikan sebagai suatu kelompok manusia yang hidup bersama di suatu wilayah dengan tata cara berpikir dan bertindak yang (relatif) sama yang membuat warga masyarakat itu menyadari diri mereka sebagai satu kesatuan (kelompok).

Demikian pengertian tentang masayarakat yang diberikan para ahli. Meskipun masih banyak pengertian yang lain, tetapi pada dasarnya tidak terlalu banyak berbeda. Yang jelas masyarakat adalah suatu perwujudan kehidupan bersama manusia, di mana di dalam masyarakat berlangsung peruses kehidupan sosial, proses anatarhubungan, dan antaraksi.

Secara kualitatif dan kuantitatif anggota masyarakat, terdiri dari berbagai ragam pendidikan, profesi, keahlian, suku bangsa, kebudayaan, agama, lapisan sosial sehingga menjadi masyarakat yang majemuk.

Dilihat dari konsep pendidikan, masyarakat adalah sekumpulan banyak orang dengan berbagai ragam kualitas diri mulai dari yang tidak berpendidikan sampai yang berpendidikan tinggi. Sementara itu, dilihat dari lingkungan pendidikan, masyarakat disebut lingkungan pendidikan nonformal yang memberikan pendidikan secara sengaja dan berencana kepada seluruh anggotanya, tetapi tidak sistematis.

Antara masyarakat dengan pendidikan punya keterkaitan dan saling berperan. Apalagi pada zaman sekarang ini, setiap orang selalu menyadari akan peranan dan nilai pendidikan. Oleh karena itu, setiap warga masyarakat bercitacita dan aktif berpatisifasi untuk membina pendidikan.

Mohammad Noor Syam, dalam bukunya Filsafat Pendidikan dan Dasar Filasafat Pancasila, mengemukakan bahwa hubungan masyarakat dengan pendidikan sangat bersifat korelatif, bahkan seperti telur dengan ayam. Masyarakat maju karena pendidikan dan pendidikan yang maju hanya akan ditemukan dalam masyarakat yang maju pula. (M. Nur Syam, 199: 1986)

Sementara itu, Sanafiah Faisal mengemukakan bahwa hubungan antar sekolah (pendidikan) dengan masyarakat paling tidak, bisa dilihat dari dua segi berikut: (Sanafiah Faisal, 148-151: 1988) 
1. Sekolah sebagai patner masyarakat di dalam melaksanakan fungsi pendidikan. Dalam konteks ini, berarti keduanya, yaitu sekolah dan masyarakat dilihat sebagai pusat-pusat pendidikan yang potensial dan mempunyai hubungan yang fungsioanal.

2. Sekolah sebagai prosedur yang melayani pesan-pesan pendidikan dari masyarakat lingkungannya. Berdasarkan hal ini, berarti antara masyrakat dengan sekolah memiliki ikatan hubungan rasional berdasarkan kepentingan di kedua belah pihak.

\section{PENUTUP}

Dari pembahsan di ats dapat diambil kesimpulan di antaranya:

1. Peran keluarga dalam pendidikan siapapun akan berpendapat sangat penting dan urgent, bahkan ada istilah alummahatul madrasatul ula, di mana tugas utama keluarga bagi pendidikan anak ialah sebagai peletak dasar bagi pendidikan akhlak dan pandangan hidup keagamaan serta menciptakan situasi belajar yang kondusif, karna sifat dan tabiat anak sebagian besar diambil dari kebiasaan dan latihan yang diterapkan oleh kedua orang tuanya dan dari anggota keluarga yang lain.

2. Hubungan keluarga dan pihak sekolah haruslah seiring seirama. Karena pada dasarnya tanggung jawab pendidikan adalah bersama antara keluarga, masyarakat, dan pemerintah. Sekolah hanyalah pembantu kelanjutan pendidikan dalam keluarga sebab pendidikan yang pertama dan utama diperoleh anak adalah dalam keluarga. Untuk itu komunikasi antara pihak keluarga dan sekolah harus intens dan perlu juga kesadaran di pihak keluarga untuk tidak "melepaskan" tanggungjawab pendidikan hanya ke sekolah saja.

3. Peran masyarakat dalam pendidikan sangatlah besar, dapat dilihat masyarakat sebagai objek pendidikan sekaligus sebagai subjek pendidikan. Lebih khusus peran masyarakat sangatlah besar 
terhadap pendidikan formal yang berlangsung di sekolah. Untuk itu, sekolah atau lembaga pendidikan perlu memanfaatkan dengan sebaik-baiknya, paling tidak bahwa proses pendidikan harus dapat mempergunakan sumber-sumber pengetahuan yang ada di masyarakat

4. Hubungan masyarakat dan pihak sekolah sangatlah erat dan bersifat korelatif, bahkan seperti telur dengan ayam. Masyarakat maju karena pendidikan dan pendidikan yang maju hanya akan ditemukan dalam masyarakat yang maju pula. Sekolah sebagai patner masyarakat di dalam melaksanakan fungsi pendidikan dan sekolah juga sebagai prosedur yang melayani pesan-pesan pendidikan dari masyarakat lingkungannya.

\section{Kritik dan Saran}

Kritik dan saran yang dapat kami sampaikan di antaranya ditujukan kepada:

1. Pihak keluarga dalam hal ini orang tua, hendaklah tidak menyerahkan sepenuhnya proses pendidikan putra-putrinya kepada pihak sekolah dengan beranggapan bahwa sekolah sudah mencukupi bagi kebutuhan pendidikan anak, akan tetapi senantiasa memantau perkembangan dan pertumbuhan anak dengan memberikan latihan dan kebiasaan yang baik sebagai bekal hidup anak nanti.

2. Pihak masyarakat sebagai lingkungan di mana anak tumbuh dan berkembang, bermain dan bergaul, hendaknya para warganya mempunyai kesadaran bahwa baik buruknya anak juga ditentukan oleh lingkungan yang menjadi habitasinya. Sehingga sebagai warga masyarakat akan memilki kepedulian terhadap siapapun yang hidup di lingkungannya.

3. Bagi pihak sekolah, hendaknya lebih rajin dan berkesinambungan dalam menjalin komunikasi dengan pihak keluarga dan masyarakat demi terwujudnya cita-cita pendidikan, dan juga rajin mencari informasi halhal yang terkait dengan kemajuan pendidikan dari masyarakat sekitar. 


\section{DAFTAR RUJUKAN}

Arifin, M Aminuddin Rasyad, Dasar-dasar Kependidikan, Dirjen. Bimbingan lslam dan Universitas Terbuka, Jakarta, 1991.

Faisal, Sanafiah dalam Tim Dosen FIP IKIP Malang, Pengantar Dasar-dasar Kependidikan, Usaha Nasional, Surabaya, 1988.

Hasbullah, Dasar-dasar llmu Pendidikan, Ed. Revisi. Jakarta, Rajawali Pers., 2009.

Tap MPR Nomor 11/MPR/1993 tentang Garis-garis Besar Haluan Negara (GBHN), Bina Pustaka Tama, Surabaya, 1993.

Ogburn \& Nimkolf, Sosiology, Houghton Mifflin Coy. New York, 1964, hlm. 291.

Robert W. Richey, planning for Teaching an Introduction to Education, Mc.Graw Hill Book Coy, New York 1968.

Noor Syam,Mohamammad, Filsafat Pendidikan dan Dasar Filasafat Pancasila, Usaha Nasional, Surabaya, 1986.

S. Sadiman,Arief Media Pendidikan, Pengertian Pengembangan dan Pemanfaatanya, Jakarta. Rajawali Pers, 2010.

Buchari Alma, Kewirausahaan, (Alfabeta, Bandung : 2009)

Syaodih Sukmadinata,Nana Landasan Psikologi Proses Pendidikan, (PT.Remaja Rosdakarya : 2007). 